\title{
Ethnic differences in urinary calcium and phosphate excretion between Gambian and British older adults
}

\author{
J. Redmond • L. Palla • L. Yan • L. M. A. Jarjou • \\ A. Prentice $\cdot$ I. Schoenmakers
}

Received: 22 January 2014 / Accepted: 1 October 2014 / Published online: 14 October 2014

(C) The Author(s) 2014. This article is published with open access at Springerlink.com

\begin{abstract}
Summary Ethnic differences in renal calcium and phosphate excretion exist, which may depend on differences in their dietary intakes and regulatory factors. We report highly significant differences in urinary calcium and phosphate excretion between white British and Gambian adults after statistical adjustment for mineral intakes, indicating an independent effect of ethnicity.

Introduction Populations vary in their risk of age-related osteoporosis. There are racial or ethnic differences in the metabolism of the bone-forming minerals calcium $(\mathrm{Ca})$ and phosphate $(\mathrm{P})$, with a lower renal $\mathrm{Ca}$ and $\mathrm{P}$ excretion in AfricanAmericans compared to white counterparts, even at similar intakes and rates of absorption. Also, Africans in The Gambia have a lower $\mathrm{Ca}$ excretion compared to white British subjects, groups known to differ in their dietary $\mathrm{Ca}$ intake. Here, we report on differences in urinary $\mathrm{Ca}$ and $\mathrm{P}$ excretion between Gambian and white British adults while allowing for known predictors, including dietary intakes.

Methods Participants were healthy white British $(n=60)$ and Gambian $(n=61)$ men and women aged $60-75$ years. Fasting blood and 2-h urine samples were collected. Markers of Ca and P metabolism were analysed. Dietary intake was assessed with country-specific methods.
\end{abstract}

J. Redmond $\cdot$ L. Palla $\cdot$ L. Yan $\cdot$ A. Prentice $\cdot$ I. Schoenmakers $(\bowtie)$ Medical Research Council Human Nutrition Research, Elsie

Widdowson Laboratory, Cambridge CB1 9NL, UK

e-mail: inez.schoenmakers@mrc-hnr.cam.ac.uk

L. M. A. Jarjou • A. Prentice

Medical Research Council Keneba, Keneba, The Gambia

Present Address:

L. Palla

Department of Non-communicable Disease Epidemiology, Faculty of Epidemiology and Population Health, London School of Hygiene and Tropical Medicine, London, UK
Results White British older adults had higher creatininecorrected urinary $\mathrm{Ca}$ and $\mathrm{P}$ excretion $(\mathrm{uCa} / \mathrm{uCr}, \mathrm{uP} / \mathrm{uCr})$ and lower tubular maximum of $\mathrm{Ca}$ and $\mathrm{P}$ compared to Gambian counterparts. The predictors of urinary $\mathrm{Ca}$ and $\mathrm{P}$ differed between groups. Multiple regression analysis showed that dietary $\mathrm{Ca}$ and $\mathrm{Ca} / \mathrm{P}$ were predictors of $\mathrm{uCa} / \mathrm{uCr}$ and $\mathrm{uP} / \mathrm{uCr}$, respectively. Ethnicity remained a significant predictor of $\mathrm{uCa} / \mathrm{uCr}$ and $\mathrm{uP} / \mathrm{uCr}$ after adjustment for diet and other factors.

Conclusions Gambian older adults have higher renal Ca conservation than British counterparts. Dietary mineral intakes were predictors of the differences in urinary $\mathrm{Ca}$ and $\mathrm{P}$ excretion, but ethnicity remained a highly significant predictor after statistical adjustment. This suggests that ethnicity has an independent effect on renal $\mathrm{Ca}$ and $\mathrm{P}$ handling.

Keywords Bone $\cdot$ Calcium $\cdot$ Diet $\cdot$ Ethnicity $\cdot$ Kidney Phosphate

\section{Introduction}

Worldwide, the prevalence of osteoporosis and the incidence of age-related fragility fracture vary by racial and/or ethnic group. Kanis et al. reported a greater than 10-fold variation in fracture probability between countries across the world [1]. The incidence rates of hip and distal forearm fractures in elderly West African men and women are substantially lower than those found in the UK [2], and similar racial or ethnic differences in fracture risk have been reported within the USA between African-Americans compared to white Americans [3]. While a higher bone mineral density (BMD) is found in African-Americans, the lower rates of fracture in Africa cannot be ascribed to a higher bone mass across the life cycle [4-6]. These differences in osteoporosis and fracture risk may be due to a plethora of factors that are important to variation in bone health. These include factors related to ancestry or race 
(here defined as 'a group of people connected by common descent') and particularly include genetic factors and those related to ethnicity (here defined as 'a group that shares a distinctive cultural and historical tradition, often associated with race, nationality or geographic region'), which include socioeconomic, dietary and other lifestyle factors [7-9]. Also, environmental differences play an important role, as evidenced by changes in fracture risk amongst populations that have migrated from their country of origin to other parts of the world [10-12].

Racial or ethnic differences in the metabolism of the boneforming minerals, calcium $(\mathrm{Ca})$ and phosphate $(\mathrm{P})$, have been reported and suggest that African-Americans and Black South Africans have lower urinary $\mathrm{Ca}$ and $\mathrm{P}$ excretion than white study participants from the same geographical region [13-15]. Studies that carefully assessed or controlled $\mathrm{Ca}$ and $\mathrm{P}$ intake showed that 24-h urinary $\mathrm{Ca}$ and $\mathrm{P}$ outputs in AfricanAmerican adults are also lower compared to white Americans when their dietary mineral intakes are similar and that this is not mediated by a lower gut $\mathrm{Ca}$ absorption [16-19]. Further, a lower urinary $\mathrm{Ca}$ and $\mathrm{P}$ excretion was found in AfricanAmericans compared to white Americans at comparable concentrations of $25(\mathrm{OH}) \mathrm{D}, 1,25(\mathrm{OH})_{2} \mathrm{D}$ and PTH [19] or FGF23 concentrations [20]. Taken together, these findings suggest that renal mineral handling may be an important factor influencing racial or ethnic differences in $\mathrm{Ca}$ and $\mathrm{P}$ balance and metabolism and that these differences may not be fully explained by differences in their dietary intake but may also be influenced by race or ethnicity and/or the adaptive response to migration [21].

Less is known about differences in renal $\mathrm{Ca}$ and $\mathrm{P}$ handling between ethnic groups living in different parts of the world. A lower 24-h urinary $\mathrm{Ca}$ excretion has been reported for African adult women living in The Gambia, West Africa, compared to white women living in the UK [22]. In The Gambia, dietary Ca intake is substantially lower throughout life than in the UK, and the regulators PTH and $1,25(\mathrm{OH})_{2} \mathrm{D}$ are higher in Gambian compared to white British study participants [5, 23]. However, plasma $25(\mathrm{OH}) \mathrm{D}$ is generally higher in individuals living in The Gambia than in the UK due to their greater opportunities for UVB sunshine exposure in this tropical African country [24]. We aimed to investigate differences in renal $\mathrm{Ca}$ and $\mathrm{P}$ excretion between two distinct ethnic groups, living in their environment of origin: white British and Gambian older adults. Ethnic differences in renal $\mathrm{Ca}$ and $\mathrm{P}$ excretion were assessed while considering the influence of dietary intake of these minerals and other predictors.

\section{Materials and methods}

This paper is a secondary analysis of data from two studies conducted at the Medical Research Council (MRC) Human
Nutrition Research (HNR), Cambridge, UK, and MRC Keneba, Keneba, The Gambia. The first study (study 1) was conducted in Cambridge $(n=30)$ and Keneba $(n=30)$ in 2005; the second study (study 2) was conducted in Cambridge ( $n=$ $30)$ in 2011 and Keneba $(n=31)$ in 2010. All procedures were conducted under the same standard operating procedures.

Ethical approval was given by the Cambridge Local Research Ethics Committee and the Gambian Government/MRC Laboratories Joint Ethics Committee. Informed written consent was obtained from all subjects. The research was performed in line with the principles outlined by the Declaration of Helsinki.

\section{Study participants}

Participants were recruited from the community through advertisements (UK) and by fieldworkers after an initial screen on eligibility through the West Kiang Surveillance database (The Gambia). They were healthy older men and women (aged 60-75 years) as defined elsewhere [5, 23]. Participants were reimbursed for their expenses.

\section{Cambridge, UK}

Participants were residents of Cambridge and the surrounding villages and were of British white descent. Cambridge (latitude $52^{\circ} \mathrm{N}$ ) is a university town in the southeast of England with a temperate climate. Studies were performed in winter when there is no cutaneous vitamin D synthesis.

\section{Keneba, The Gambia}

Participants were residents of Keneba and the surrounding villages and were of African (predominantly Mandinka) descent. Keneba (latitude $13^{\circ} \mathrm{N}$ ) is a rural village in The Gambia, and the climate is tropical, hot and sunny all year with a wet season (June-November) and a dry season from November to June. Studies were performed in the dry season.

Anthropometry

Weight and height were measured, and body mass index (BMI) was calculated (weight/height ${ }^{2}$ ) and body surface area (BSA) as $(\text { weight } \times(\text { height } / 3600))^{1 / 2}$ [25]. Blood pressure (BP) was measured using an automated BP monitor (Omron, Omron Healthcare Europe).

Dietary analysis

Dietary $\mathrm{Ca}$ and $\mathrm{P}$ intakes were assessed using methods appropriate for each country. In the UK, dietary intake was recorded using food frequency questionnaires in study 1 and a 4-day food diary in study 2 . These methods use the same food 
composition tables [26] and were shown to be in good agreement [27]. Potential differences in dietary intakes in $\mathrm{Ca}$ and $\mathrm{P}$ intakes between studies 1 and 2 were explored by $t$ tests and inclusion of a dummy variable for study (Table 1 ). These were non-significant. In The Gambia, dietary intake was assessed using a 2-day weighed food diary in both studies [28]. All dietary data were analysed at MRC-HNR using British [26] and Gambian [29] food composition tables respectively.

\section{Sample collection}

Venous blood samples were obtained from the antecubital fossa after an overnight fast in ethylenediaminetetraacetic acid (EDTA) and lithium heparinised (LH) tubes at 7.00 or 9.00 a.m. ( $\pm 5 \mathrm{~min}$ ). Ionised calcium (iCa) was measured within $15 \mathrm{~min}$ in LH blood with a blood gas and electrolyte analyser (ABL 77, Radiometer Ltd., West Sussex, UK). The remainder of the blood samples were processed, stored and analysed as described before [5, 23]. The timed 2-h urine collections were obtained at the respective research centres from 7.00 to 9.00 a.m. ( $\pm 5 \mathrm{~min}$ ) after an overnight fast and voiding the first morning urine. Urine samples were kept cool until processing and storage; unacidified and acidified aliquots were frozen at $-20^{\circ} \mathrm{C}$.

\section{Biochemical analyses}

Measurement of all analytes was conducted in duplicate, except for blood iCa and in study 1 for those markers analysed by Elecsys (see below) and in study 2 for PTH, for which measurements were performed once.

In both studies, plasma total calcium $(\mathrm{Ca})$, phosphate $(\mathrm{P})$, creatinine ( $\mathrm{Cr}$ ) and albumin (Alb) (pCa, pP, pCr and $\mathrm{pAlb}$ ); 1,25-dihydroxyvitamin $\mathrm{D}\left(1,25(\mathrm{OH})_{2} \mathrm{D}\right)$ in LH plasma; and urinary $\mathrm{Ca}, \mathrm{P}$ and $\mathrm{Cr}(\mathrm{uCa}$, $\mathrm{uP}$ and $\mathrm{uCr}$ ) were measured as detailed elsewhere [5, 23]. C-terminal fibroblast growth factor-23 (FGF-23) was measured by ELISA (Immunodiagnostics System PLC, Tyne \& Wear, UK) in EDTA plasma. Within- and between-assay CV were $<2.0$ and $<2.5 \%$.

In study 1 , parathyroid hormone (PTH), total $\mathrm{N}$-terminal propeptide of type 1 procollagen (P1NP), N-mid osteocalcin (OC) and $\beta$-form of cross-linked $\mathrm{C}$-telopeptide of type 1 collagen (CTX) were measured on an automatic analyser (Elecsys 2010, Roche Diagnostics, USA) in EDTA plasma. Between-assay CV was 4.7, 3.2, 3.1 and $4.3 \%$ respectively. The OC assay detects both the intact molecule and N-terminal fragment. Plasma bone alkaline phosphatase (BAP) was measured by ELISA (Metra BAP EIA kit, Quidel Corporation, USA) in LH plasma. Within- and between-assay CV were 2.1 and $7.9 \%$. Plasma 25 -vitamin D $(25(\mathrm{OH}) \mathrm{D})$ was measured by radioimmunoassay (DiaSorin, Stillwater, MN, USA) in LH plasma. Within- and between-assay CV were 4.1 and $6.1 \%$.

In study 2, P1NP was measured by radioimmunoassay (Uniq P1NP, Orion Diagnostica, Finland) in EDTA plasma. Within- and between-assay CV were $<2$ and $<1.5 \%$. CTX was measured by ELISA (Immunodiagnostics System PLC, Tyne \& Wear, UK) in LH plasma. Within- and between-assay $\mathrm{CV}$ were $<3$ and $<3.5 \%$. PTH was measured with an automated chemiluminescence assay (Immulite, Siemens Healthcare Diagnostics, Surrey, UK) in EDTA plasma. Between-assay CV was $3.5 \%$. BAP, OC and 25(OH)D were measured using a chemiluminescence immunoassay with an automated analyser (Liaison, Diasorin, Bracknell, UK) in LH plasma. Within- and between-assay $\mathrm{CV}$ were both $<4.0 \%$ for BAP and $<3$ and $<3.5 \%$ for OC respectively. For $25(\mathrm{OH}) \mathrm{D}$, within-assay $\mathrm{CV}$ was $<5 \%$ and samples were measured in one run.

Assay performance was monitored using kit and in-house controls and by participation in the Vitamin D External Quality Assessment Scheme (www.deqas.org) for 25(OH)D, and the UK National External Quality Assessment Service (www. ukneqas.org.uk) for PTH.

\section{Derived variables}

The albumin-adjusted $\mathrm{pCa}(\mathrm{pCaAlb}(\mathrm{mmol} / \mathrm{l}))$ was normalised to an albumin concentration of $40 \mathrm{~g} / \mathrm{l}$ using the Payne equation $(\mathrm{pCa}+(40-\mathrm{Alb}(\mathrm{g} / \mathrm{l})) \times 0.02)[30]$. This equation was used for data from both ethnic groups, as before [31]. Regression analysis of the Ca-Alb relationship showed similar coefficients for both groups ( 0.03 and 0.02 for the UK and The Gambia, respectively) and the group interaction term was nonsignificant $(P=0.2)$, indicating that there were no significant differences in the relationship of these variables between these two groups.

Concentrations of $\mathrm{uCa}$ and $\mathrm{uP}$ were expressed as a ratio relative to $\mathrm{uCr}$ to adjust for urine volume $(\mathrm{uCa} / \mathrm{uCr}, \mathrm{uP} / \mathrm{uCr}$ $(\mathrm{mmol} / \mathrm{mmol}))$ and as total mineral excretion per collection ( $2 \mathrm{~h}$ timed collection) $(\mathrm{uCa} / 2 \mathrm{~h}, \mathrm{uP} / 2 \mathrm{~h},(\mathrm{mmol} / 2 \mathrm{~h}))$. Fractional mineral excretion (i.e. the proportion of mineral filtered by the kidney that is excreted in the urine) was calculated using the following formulae: the fractional excretion of $\mathrm{Ca}$ $(\mathrm{FECa})=(\mathrm{uCa} \times \mathrm{pCr}) /(\mathrm{pCa} \times \mathrm{uCr}) \times 100$ [32] and of $\mathrm{P}$ $(\mathrm{FEP})=(\mathrm{uP} \times \mathrm{pCr}) /(\mathrm{pP} \times \mathrm{uCr}) \times 100$ [33]. The renal threshold for $\mathrm{Ca}(\mathrm{TmCa} / \mathrm{GFR}(\mathrm{mmol} / \mathrm{l} \mathrm{GFR}))$ and for $\mathrm{P}(\mathrm{TmP} / \mathrm{GFR}$ (mmol/l GFR)) were calculated as follows: $\mathrm{TmCa} / \mathrm{GFR}=((0.56 \times \mathrm{pCa})-(\mathrm{uCa} / \mathrm{uCr}) \times \mathrm{pCr}) /(1-$ $0.08 \operatorname{loge}(0.56 \times \mathrm{pCa} /(\mathrm{uCa} / \mathrm{uCr}) \times \mathrm{pCr})[32]$ and $\mathrm{TmP} / \mathrm{GFR}=(\mathrm{a})$ $\mathrm{TRP} \times \mathrm{pP}$ if TRP $\leq 0.86$ and (b) $\alpha \times \mathrm{pP}$ if TRP $>0.86$, where $\mathrm{TRP}=(1-((\mathrm{uP} / \mathrm{pP}) \times(\mathrm{pCr} / \mathrm{uCr})))$ and $\alpha=(0.3 \times \mathrm{TRP} /(1-(0.8 \times$ TRP))) [34]. 
Table 1 Characteristics of participants, regulatory factors and bone turnover markers and markers of renal function and renal calcium and phosphate handling

\begin{tabular}{|c|c|c|c|c|}
\hline & \multirow{2}{*}{$\begin{array}{l}\text { British } \\
N=60\end{array}$} & \multirow{2}{*}{$\begin{array}{l}\text { Gambian } \\
N=61\end{array}$} & \multicolumn{2}{|c|}{ Ethnic differences ${ }^{\mathrm{a}}$} \\
\hline & & & $P$ & Sympercent $\% \Delta \mathrm{G}-\mathrm{B}(95 \% \mathrm{CI})$ \\
\hline \multicolumn{5}{|l|}{ Characteristics of participants } \\
\hline Age, years & $66(0.5)$ & $67(0.5)$ & 0.4 & $+1(-1,+2)$ \\
\hline Weight, $\mathrm{kg}$ & $78(2)$ & $57(1)$ & $<0.001$ & $-31(-37,-25)$ \\
\hline Height, m & $1.69(0.01)$ & $1.61(0.01)$ & $<0.001$ & $-5(-7,-3)$ \\
\hline BMI, $\mathrm{kg} / \mathrm{m}^{2 \mathrm{~d}}$ & $26.9(0.6)$ & $21.5(0.3)$ & $<0.001$ & $-21(-27,-17)$ \\
\hline $\mathrm{BSA}, \mathrm{m}^{2}$ & $1.91(0.02)$ & $1.59(0.01)$ & $<0.001$ & $-18(-22,-14)$ \\
\hline Systolic BP, mmHg & $129(2)$ & $125(2)$ & 0.2 & $-3(-8,1)$ \\
\hline Diastolic BP, mmHg & $77(1)$ & $72(1)$ & 0.005 & $-6(-10,-2)$ \\
\hline Energy $^{\mathrm{b}}, \mathrm{kcal} /$ day & $2234(75)$ & $1664(69)$ & $<0.001$ & $-31(-42,-20)$ \\
\hline Dietary $\mathrm{Ca}^{\mathrm{b}}, \mathrm{mg} /$ day & $1152(34)$ & $303(17)$ & $<0.001$ & $-139(-152,-126)$ \\
\hline Dietary $\mathrm{P}^{\mathrm{b}}, \mathrm{mg} /$ day & $1525(35)$ & $727(32)$ & $<0.001$ & $-78(-88,-67)$ \\
\hline Dietary Ca:P, mg/mg & $0.75(.01)$ & $0.41(0.01)$ & $<0.001$ & $-61(-68,-54)$ \\
\hline $\mathrm{iCa}, \mathrm{mmol} / \mathrm{L}$ & $1.17(0.1)$ & $1.18(.01)$ & 0.7 & $+1(-2,+3)$ \\
\hline $\mathrm{pCa}, \mathrm{mmol} / \mathrm{L}$ & $2.36(0.02)$ & $2.24(0.01)$ & $<0.001$ & $-5(-7,-2)$ \\
\hline $\mathrm{pAlb}, \mathrm{mmol} / \mathrm{L}$ & $38.3(0.4)$ & $35.6(0.5)$ & $<0.001$ & $-8(-11,-4)$ \\
\hline $\mathrm{pCaAlb}, \mathrm{mmol} / \mathrm{L}^{\mathrm{d}}$ & $2.39(0.02)$ & $2.32(0.02)$ & 0.01 & $-2(-4,-1)$ \\
\hline $\mathrm{pP}, \mathrm{mmol} / \mathrm{L}$ & $1.03(0.01)$ & $1.08(0.02)$ & 0.2 & $+4(-2,+9)$ \\
\hline \multicolumn{5}{|l|}{ Regulatory factors and bone turnover markers } \\
\hline $25(\mathrm{OH}) \mathrm{D}^{\mathrm{b}}, \mathrm{nmol} / \mathrm{L}$ & $46(2)$ & $62(2)$ & $<0.001$ & $+35(+22,+48)$ \\
\hline $\mathrm{PTH}^{\mathrm{b}}, \mathrm{pg} / \mathrm{ml}^{\mathrm{d}}$ & $37.9(4)$ & $70(5)$ & $<0.001$ & $+45(+30,+60)$ \\
\hline $1,25(\mathrm{OH})_{2} \mathrm{D}, \mathrm{pmol} / \mathrm{L}^{\mathrm{d}}$ & $114(5)$ & $185(6)$ & $<0.001$ & $+48(+38,+58)$ \\
\hline FGF-23, RU/ml ${ }^{\mathrm{d}}$ & $52(4)$ & $63(8)$ & 0.2 & $+18(-10,+47)$ \\
\hline Klotho, $\mathrm{pg} / \mathrm{ml}^{\mathrm{c}}$ & $663(32)$ & $664(50)$ & 0.6 & $-6(-26,+14)$ \\
\hline $\mathrm{P} 1 \mathrm{NP} \mathrm{b}^{\mathrm{b}}, \mu \mathrm{g} / \mathrm{L}^{\mathrm{d}}$ & $38(2)$ & $69(4)$ & $<0.001$ & $+58(+42,+73)$ \\
\hline $\mathrm{CTX}^{\mathrm{b}}, \mathrm{ng} / \mathrm{ml}^{\mathrm{d}}$ & $0.34(0.02)$ & $0.72(0.04)$ & $<0.001$ & $+74(+57,+91)$ \\
\hline $\mathrm{OC}^{\mathrm{b}}, \mathrm{ng} / \mathrm{ml}^{\mathrm{d}}$ & $14(1)$ & $27(2)$ & $<0.001$ & $+63(+42+84)$ \\
\hline $\mathrm{BAP}^{\mathrm{b}}, \mu \mathrm{g} / \mathrm{L}^{\mathrm{d}}$ & $15(1)$ & $21(2)$ & $<0.001$ & $+32(+9,+54)$ \\
\hline \multicolumn{5}{|c|}{ Markers of renal function and renal calcium and phosphate handling } \\
\hline Ccr (BSA-corrected), $\mathrm{ml} / \mathrm{min}$ & $89(7)$ & $81(8)$ & 0.4 & $-18(-45,+9)$ \\
\hline $\mathrm{uCa} / \mathrm{uCr}, \mathrm{mmol} / \mathrm{mmol}^{\mathrm{d}}$ & $0.29(0.02)$ & $0.08(0.01)$ & $<0.001$ & $-121(-154,-88)$ \\
\hline $\mathrm{uCa}, \mathrm{mmol} / 2 \mathrm{~h}^{\mathrm{d}}$ & $0.24(0.02)$ & $0.06(0.01)$ & $<0.001$ & $-139(-192,-85)$ \\
\hline $\mathrm{FECa}, \%^{\mathrm{d}}$ & $1.07(0.07)$ & $0.28(0.04)$ & $<0.001$ & $-132(-165,99)$ \\
\hline $\mathrm{TmCa} / \mathrm{GFR}^{\mathrm{d}}, \mathrm{mmol} / \mathrm{l} \mathrm{GFR}$ & $1.88(0.02)$ & $2.18(0.05)$ & $<0.001$ & $+14(+8,+20)$ \\
\hline TmCa/GFR (BSA-corrected), mmol/lGFR & $1.7(0.03)$ & $2.4(0.08)$ & $<0.001$ & $+33(+25,+40)$ \\
\hline $\mathrm{uP} / \mathrm{uCr}, \mathrm{mmol} / \mathrm{mmol}^{\mathrm{d}}$ & $1.63(0.08)$ & $1.22(0.08)$ & $<0.001$ & $-29(-45,-12)$ \\
\hline $\mathrm{uP}, \mathrm{mmol} / 2 \mathrm{~h}^{\mathrm{d}}$ & $1.55(0.12)$ & $0.51(0.07)$ & $<0.001$ & $-111(-143,-79)$ \\
\hline FEP, \% & $14.5(0.6)$ & $9.2(0.5)$ & $<0.001$ & $-49(-65,-33)$ \\
\hline $\mathrm{TmP} / \mathrm{GFR}, \mathrm{mmol} / \mathrm{l} \mathrm{GFR}$ & $0.91(0.01)$ & $1.11(0.03)$ & $<0.001$ & $+18(+10,+25)$ \\
\hline TmP/GFR (BSA-corrected), mmol/lGFR & $0.83(0.02)$ & $1.21(0.03)$ & $<0.001$ & $+36(+28,+45)$ \\
\hline
\end{tabular}

For normally distributed data, results are expressed as mean (SE). For positively skewed data, the results are expressed as geometric mean (SE). Data were derived from mixed model regression analysis. The value of a sympercent difference is the coefficient of the variable following regression of its transformed 100 ln value with ethnicity

$B M I$ body mass index, $B P$ blood pressure, $k c a l$ kilocalorie, $C a$ calcium, $P$ phosphate, $i C a$ ionised calcium, $p C a$ plasma calcium, $p A l b$ plasma albumin, $p C a A l b$ plasma-corrected calcium, $p P$ plasma phosphate, $25(O H) D 25$-hydroxy vitamin $\mathrm{D}, P T H$ parathyroid hormone, $F G F$ - 23 fibroblast growth factor23, $P 1 N P$ procollagen amino-terminal propeptide, $C T X$ carboxy-terminal telopeptide, $O C$ osteocalcin, $B A P$ bone alkaline phosphatase, $C c r$ creatinine clearance, $B S A$ body surface area, $u C a$ urinary calcium, $u C r$ urinary creatinine, $F E C a$ fractional excretion of calcium, $T m C a / G F R$ tubular maximum of calcium, GFR glomerular filtration rate, $u P$ urinary phosphate, $F E P$ fractional excretion of phosphate, TmP/GFR tubular maximum of phosphate

${ }^{a}$ Ethnic differences tested using regression model with ethnicity as an independent binary variable

${ }^{\mathrm{b}}$ A dummy variable to adjust for study methodology was included for dietary variables, plasma 25(OH)D, PTH, P1NP,OC, BAP and CTX; this was significant for OC, BAP and CTX $(P<0.05)$

${ }^{\mathrm{c}} n=61$ (measured in study 2 only)

${ }^{\mathrm{d}}$ Positively skewed data 
Glomerular filtration rate (eGFR) was calculated using the CKD-EPI formula without a variable for race, as appropriate for a West African population [35]. Creatinine clearance (Ccr) was calculated as $(\mathrm{uCr} \times \operatorname{urine}(\mathrm{ml} / \mathrm{min})) / \mathrm{pCr}$.

\section{Data handling and statistical analysis}

Statistical analysis was carried out using Stata 11.1 (StataCorp LP, TX, USA). Distribution of data was assessed with inspection of histograms and QQ normality plots.

There were five participants in The Gambia and three participants in the UK who took part in both study 1 and study 2. To allow for the inclusion of paired data points, a maximum likelihood regression model was used that takes account of the correlation between repeated measures on the same subject (mixed model with random intercept). The descriptive results represent the mean (SE) as derived from mixed model regression. Non-normally distributed data descriptive statistics are given as geometric mean (SE). Descriptive data are expressed in standard units and as group percentage (sympercent) differences. The latter allows the comparison of proportional differences between groups, and proportional relationships between dependent and independent variables in a regression analysis. For this purpose, continuous variables were transformed to natural logarithms (ln), and ethnicity was used as a binary independent variable. The sympercent represents the difference (ln derived difference $\times 100$ ) between groups [36] There were significant differences between men and women in some baseline characteristics, similar to those reported before $[5,23]$. However, there were no significant ethnicitygender interactions identified for the outcomes of interest. Therefore, the data for each group are presented for men and women combined. Ethnic differences in all variables were tested using mixed model regression that accommodates within subject correlation and adjustment for covariates, with ethnicity as a binary independent variable (Table 1).

Statistical approach to investigating ethnic differences in urinary mineral excretion

In order to investigate the predictors of $\mathrm{uCa} / \mathrm{uCr}$ within each ethnic group, exploratory simple regression analysis of the possible predictors of $\mathrm{uCa} / \mathrm{uCr}$ was conducted in data from The UK and The Gambia separately (Table 2). To follow on from this, we conducted regression analysis in the combined data set with adjustment for ethnicity and an interaction term for the independent variable and ethnicity; the interaction term was removed if non-significant (Table 3).

Multiple regression analysis was conducted with a starting model including biologically plausible predictors of $\mathrm{uCa} / \mathrm{uCr}$, both with and without an adjustment for ethnicity (Table 4). The multiple regression was carried out using the mixed effects regression analysis, although the results (both effect size and $P$ values) were similar when they were checked using ordinary linear regression. A backwards selection approach was used to identify significant predictors based on $P$ values of Wald tests. This backward elimination algorithm yielded virtually the same final models as per Akaike's Information Criteria (AIC) approach (results not presented). Residual diagnostic checks were carried out following regression analysis. Predictors included in the starting multiple regression model were age, sex, weight (or height or BMI), iCa, pP, $25(\mathrm{OH}) \mathrm{D}, 1,25(\mathrm{OH})_{2} \mathrm{D}, \mathrm{PTH}, \mathrm{FGF}$ (or Klotho), P1NP (or OC, BAP, CTX) and dietary Ca (or dietary energy in kcal, dietary $\mathrm{P}$, or dietary $\mathrm{Ca} / \mathrm{P}$ ). The variables in parentheses indicate those variables that were highly correlated. Correlation between predictors was assessed prior to inclusion and predictors exhibiting high correlation (e.g. Pearson correlation $>0.6$ ) were not included in the same model to avoid collinearity. Models were run without and with ethnicity as an independent variable. The interaction terms with ethnicity were dropped in these models as they were not significant. After adjustment for ethnicity in the multiple regression analysis, dietary $\mathrm{Ca}$ was no longer a predictor of $\mathrm{uCa} / \mathrm{uCr}$. To assess the independent effects of dietary $\mathrm{Ca}$ and ethnicity, dietary $\mathrm{Ca}$ was forced into the final multiple regression model that included ethnicity. Identical analyses were performed for $\mathrm{uP} / \mathrm{uCr}$ as the dependent variable.

\section{Correction for urinary creatinine}

uCr may be influenced by muscle mass which may differ between ethnic groups. In order to assess the appropriateness of the group comparison of the derived variable $\mathrm{uCa} / \mathrm{uCr}$ or $\mathrm{uP} / \mathrm{uCr}$, regression analyses were repeated with $\mathrm{uCa}$ or $\mathrm{uP}$ as a dependent variable, while adjusting for $\mathrm{u} \mathrm{Cr}$ as an independent variable. The results showed similar patterns. Therefore, those for $\mathrm{uCa} / \mathrm{uCr}$ and $\mathrm{uP} / \mathrm{uCr}$ are presented. We also compared ethnic differences in $\mathrm{uCa} / \mathrm{uCr}$ corrected for body weight, $\mathrm{BMI}$ and BSA, which did not change the pattern of results.

\section{Correction for assay methodology}

The assay methodology differed between study 1 and study 2 for 25(OH)D, PTH, P1NP, OC, BAP and CTX. For 25(OH)D, $R^{2}$ was 0.72 , and the intercept and coefficient of the regression line were not significantly different from the line of identity. Therefore, no correction factor for study was applied. For PTH, a correction factor was applied to values obtained for study 1 based on cross-calibration of study samples by both methodologies. For P1NP, OC, BAP and CTX, crosscalibration could not be fully performed due to differences between assays in the required sample, the withdrawal of the Elecsys 2010 platform for research purposes and limitations of the remaining plasma volume. For these variables, a dummy 
Table 2 Simple regression analysis: predictors of $\mathrm{uCa} / \mathrm{uCr}(\mathrm{ln}$, $\mathrm{mmol} / \mathrm{mmol}$ ) in British and Gambian participants

\begin{tabular}{|c|c|c|}
\hline Independent variable & $\begin{array}{l}\text { British }(n=60) \\
\text { Coeff. }(95 \% \text { CI) }\end{array}$ & $\begin{array}{l}\text { Gambian }(n=61) \\
\text { Coeff. }(95 \% \text { CI) }\end{array}$ \\
\hline Age & $-0.01(-0.04,0.02)^{\mathrm{b}}$ & $-0.05(-0.11,0.01)$ \\
\hline $\operatorname{Sex}^{\mathrm{a}}$ & $-0.13(-0.30,0.15)^{*}$ & $0.14(-0.20,0.78)$ \\
\hline (ln)Weight & $-0.22(-0.99,0.54)$ & $0.98(-0.97,2.95)$ \\
\hline$(\ln ) \mathrm{Ht}$ & $-2.03(-4.47,0.40)$ & $6.45(1.16,11.7)^{*}$ \\
\hline (ln)BMI & $0.21(-0.65,1.06)$ & $-0.97(-3.36,1.42)$ \\
\hline$(\ln ) \mathrm{iCa}$ & $4.21(1.50,6.92)^{*}$ & $2.45(-1.64,6.55)$ \\
\hline (ln)pCaAlb & $0.55(-2.06,3.18)$ & $1.08(-4.10,6.28)$ \\
\hline$(\ln ) \mathrm{pP}$ & $0.09(-1.01,1.21)$ & $-1.68(-2.88,-048)^{* *}$ \\
\hline$(\ln ) 25(\mathrm{OH}) \mathrm{D}$ & $0.04(-0.27,0.37)$ & $-0.31(-1.21,0.59)$ \\
\hline$(\ln ) 1,25(\mathrm{OH})_{2} \mathrm{D}$ & $0.05(-0.43,0.54)$ & $0.02(-0.84,0.87)$ \\
\hline (ln)PTH & $-0.11(-0.33,0.10)$ & $-0.09(-0.57,0.39)$ \\
\hline$(\ln ) \mathrm{FGF}$ & $-0.16(-0.38,0.06)$ & $0.02(-0.23,0.27)$ \\
\hline$(\ln ) K_{1} \operatorname{lotho}^{\mathrm{c}}$ & $0.20(-0.46,0.88)$ & $0.42(-0.33,1.19)$ \\
\hline$(\ln ) \mathrm{P} 1 \mathrm{NP}$ & $0.46(0.12,0.80)^{* *}$ & $0.87(0.26,1.48)^{* *}$ \\
\hline$(\ln ) \mathrm{OC}^{\mathrm{d}}$ & $0.35(0.13,0.57)^{*}$ & $0.25(-0.15,0.65)$ \\
\hline$(\ln ) \mathrm{BAP}^{\mathrm{d}}$ & $0.23(0.02,0.43)^{*}$ & $0.28(-0.05,0.62)$ \\
\hline$(\ln ) \mathrm{CTX}^{\mathrm{d}}$ & $0.37(0.08,0.66)^{*}$ & $0.48(-0.10,1.07)$ \\
\hline (ln)Diet energy & $-0.34(-0.89,0.20)$ & $-0.42(-1.09,0.26)$ \\
\hline (ln)Diet $\mathrm{Ca}$ & $-0.41(-0.99,0.16)$ & $-0.19(-0.81,0.43)$ \\
\hline (ln)Diet P & $-0.49(-1.21,0.22)$ & $-0.70(-1.30,-0.09)^{*}$ \\
\hline (ln)Diet $\mathrm{Ca} / \mathrm{P}$ & $-0.29(-1.32,0.72)$ & $0.90(0.12,1.68)^{*}$ \\
\hline
\end{tabular}

For units and abbreviations, see Table 1

${ }^{a}$ Sex: female $=0$, male $=1$

${ }^{\mathrm{b}}$ The coefficient represents the sympercent difference in $\mathrm{uCa} / \mathrm{uCr}$ per unit of the independent variable (i.e. for independent variables in standard units: every unit change corresponds with a [coefficient $\times 100 \%$ ] increase in the dependent variable; for ln-converted independent variables, every $1 \%$ change corresponds with a [coefficient $\times 100 \%$ ] increase in the dependent variable)

${ }^{\mathrm{c}}$ Regression analysis with $n=30$ in the UK and $n=31$ in The Gambia

${ }^{\mathrm{d}}$ Dummy variable for study was included

$* P<0.05 ; * * P<0.01$

variable for study was added in the regression models to correct for methodology.

\section{Results}

Table 1 shows the results for subject characteristics, regulatory factors and bone turnover markers and markers of renal $\mathrm{Ca}$ and $\mathrm{P}$ handling respectively. White British participants had significantly higher body weight, height, BMI, BSA, diastolic BP, dietary intake of energy, $\mathrm{Ca}$ and $\mathrm{P}, \mathrm{pCa}, \mathrm{pAlb}$ and $\mathrm{pCaAlb}$ compared to Gambian participants. There were no ethnic differences in systolic $\mathrm{BP}, \mathrm{iCa}$ or $\mathrm{pP}$.
Table 3 Simple regression analysis: predictors of $\mathrm{uCa} / \mathrm{uCr}(\mathrm{ln}$, $\mathrm{mmol} / \mathrm{mmol}$ ) in combined data from British and Gambian participants $(n=121)$

\begin{tabular}{lll}
\hline & $\begin{array}{l}\text { Independent variable } \\
\text { Coeff. }(95 \% \mathrm{CI})\end{array}$ & $\begin{array}{l}\text { Ethnicity }{ }^{\mathrm{b}, \mathrm{c}} \\
\text { Coeff. }(95 \% \mathrm{CI})\end{array}$ \\
\hline Age & $-0.03(-.07,0.01)$ & $-1.20(-1.52,-0.87)^{* *}$ \\
Sex $^{\mathrm{a}}$ & $0.03(-0.28,0.35)$ & $-1.21(-1.54,-0.88)^{* *}$ \\
$(\ln ) \mathrm{Weight}$ & $0.18(-0.78,1.13)$ & $-1.16(-1.60,-0.71)^{* *}$ \\
$(\ln ) \mathrm{Ht}$ & $-2.20(-5.98,1.57)$ & $-5.29(-8.14,-2.45)$ \\
$(\ln ) \mathrm{BMI}$ & $-0.20(-1.31,0.90)$ & $-1.26(-1.67,-0.85)^{* *}$ \\
$(\ln ) \mathrm{iCa}$ & $3.32(0.67,5.97)^{*}$ & $-1.21(-1.54,-0.89)^{* *}$ \\
$(\ln ) \mathrm{pCaAlb}$ & $0.79(-2.24,3.82)$ & $-1.18(-1.52,-0.84)^{* *}$ \\
$(\ln ) \mathrm{pP}$ & $-0.02(-1.66,1.63)$ & $-1.05(-1.38,-0.73)$ \\
$(\ln ) 25(\mathrm{OH}) \mathrm{D}$ & $-0.05(-0.47,0.36)$ & $-1.22(-1.58,-0.86)^{* *}$ \\
$(\ln ) 1,25(\mathrm{OH})_{2} \mathrm{D}$ & $-0.02(-0.57,0.53)$ & $-1.19(-1.62,-0.77)^{* *}$ \\
$(\ln ) \mathrm{PTH}$ & $-0.09(-0.35,0.17)$ & $-1.07(-1.43,-0.71)^{* *}$ \\
$(\ln ) \mathrm{FGF}$ & $0.001(-0.19,0.19)$ & $-1.19(-1.52,-0.86)^{* *}$ \\
$(\ln ) \mathrm{Klotho}$ & $0.37(-1.56,0.91)$ & $-0.81(-1.22,-0.39)^{* *}$ \\
$(\ln ) \mathrm{P} 1 \mathrm{NP}$ & $0.70(0.35,1.05)^{* *}$ & $-1.56(-1.92,-1.20)^{* *}$ \\
$(\ln ) \mathrm{OC}{ }^{\mathrm{d}}$ & $0.65(0.28,1.02)^{* *}$ & $-1.57(1.95,-1.19)^{* *}$ \\
$(\ln ) \mathrm{BAP}$ & $0.58(0.22,0.94)^{* *}$ & $-1.42(-1.74,-1.06)^{* *}$ \\
$(\ln ) \mathrm{CTX}{ }^{\mathrm{d}}$ & $0.49(0.16,0.83)^{* *}$ & $-1.51(-1.90,-1.21)^{* *}$ \\
$(\ln ) \mathrm{Diet}$ energy & $-0.26(-0.76,0.24)$ & $-1.29(-1.65,-0.92)^{* *}$ \\
$(\ln ) \mathrm{Diet} \mathrm{Ca}$ & $-0.21(-0.66,0.23)$ & $-1.51(-2.22,-0.80)^{* *}$ \\
$(\ln ) \mathrm{Diet} \mathrm{P}$ & $-0.47(-1.01,0.05)$ & $-1.58(-2.10,-1.06)^{* *}$ \\
$(\ln ) \mathrm{Diet} \mathrm{Ca} / \mathrm{P}$ & $0.39(-0.34,1.14)$ & $-0.96(-1.53,-0.40)^{* *}$ \\
& &
\end{tabular}

For units and abbreviations, see Table 1. For interpretation of the coefficients, see Table 2

${ }^{\text {a }}$ Sex: female $=0$, male $=1$

${ }^{\mathrm{b}}$ Ethniciy white British $=0$, Gambia $=1$

${ }^{\mathrm{c}}$ If there was a significant interaction between ethnicity and the independent variable, the results of the model with an interaction term is shown and indicated in italics. If the ethnicity interaction term was not significant, the result of regression analysis with the predictor of interest and ethnicity as two independent variables is shown. The coefficient of the height $\times$ ethnicity interaction was $\beta=8.30(2.65,13.9), P=0.004$; the coefficient for the $\mathrm{pP} \times$ ethnicity interaction was $\beta=-2.03(-4.03,-0.04)$, $P=0.045$

${ }^{\mathrm{d}}$ Dummy variable for study was included

${ }^{\mathrm{e}}$ Regression analysis with $n=30$ in the UK and $n=31$ in The Gambia $* P<0.05 ; * * P<0.01$

White British participants had significantly lower plasma $25(\mathrm{OH}) \mathrm{D}, 1,25(\mathrm{OH})_{2} \mathrm{D}$ and PTH. There were no ethnic differences in plasma FGF-23 or Klotho. Plasma CTX, P1NP, $\mathrm{OC}$ and BAP were lower in white British compared to Gambian participants.

White British participants had higher $\mathrm{uCa} / \mathrm{uCr}, \mathrm{uCa} / 2 \mathrm{~h}$, FECa and lower TmCa/GFR. Between-group differences in $\mathrm{TmCa} / \mathrm{GFR}$ were greater when corrected for BSA. Similar ethnic differences were observed for renal $P$ handling. eGFR was higher in Gambian participants, but there was a similar BSA-corrected Ccr between groups. 
Table 4 Multiple regression analysis: predictors of $\mathrm{uCa} / \mathrm{uCr}(\mathrm{ln}, \mathrm{mmol} / \mathrm{mmol})$ in combined data from British and Gambian participants $(n=121)$

\begin{tabular}{|c|c|c|c|c|c|c|c|c|}
\hline \multicolumn{3}{|c|}{ Without ethnicity included } & \multicolumn{3}{|c|}{ With ethnicity included } & \multicolumn{3}{|c|}{ With dietary $\mathrm{Ca}$ forced in } \\
\hline & Coeff. & $P$ & & Coeff. & $P$ & & Coeff. & $P$ \\
\hline (ln)Diet Ca & $\begin{array}{l}0.74 \\
(0.49,0.99)\end{array}$ & $<0.001$ & Ethnicity $^{\mathrm{a}}$ & $\begin{array}{l}-1.46 \\
(-1.82,-1.10)\end{array}$ & $<0.001$ & Ethnicity & $\begin{array}{l}-1.46 \\
(-2.08,-0.84)\end{array}$ & $<0.001$ \\
\hline$(\ln ) \mathrm{iCa}^{\mathrm{b}}$ & $\begin{array}{l}3.99 \\
(1.44,6.53)\end{array}$ & 0.002 & $(\ln ) \mathrm{iCa}^{\mathrm{b}}$ & $\begin{array}{l}4.25 \\
(1.92,6.58)\end{array}$ & $<0.001$ & $(\ln ) \mathrm{iCa}^{\mathrm{b}}$ & $\begin{array}{l}4.35 \\
(2.00,6.70)\end{array}$ & $<0.001$ \\
\hline$(\ln ) \mathrm{pP}$ & $\begin{array}{l}-1.57 \\
(-2.47,-0.66)\end{array}$ & 0.001 & $(\ln ) \mathrm{pP}$ & $\begin{array}{l}-1.53 \\
(-2.37,-0.69)\end{array}$ & $<0.001$ & $(\ln ) \mathrm{pP}$ & $\begin{array}{l}-1.51 \\
(-2.35,-0.67)\end{array}$ & $<0.001$ \\
\hline \multirow[t]{2}{*}{$(\ln ) \mathrm{CTX}^{\mathrm{b}}$} & $\begin{array}{l}0.37 \\
(0.03,0.70)\end{array}$ & 0.029 & $(\ln ) \mathrm{CTX}^{\mathrm{b}}$ & $\begin{array}{l}0.49 \\
(0.19,0.79)\end{array}$ & 0.001 & $(\ln ) \mathrm{CTX}^{\mathrm{b}}$ & $\begin{array}{l}0.49 \\
(0.18,0.80)\end{array}$ & 0.002 \\
\hline & & & & & & (ln)Diet Ca & $\begin{array}{l}-0.005 \\
(-0.40,0.28)\end{array}$ & 0.97 \\
\hline
\end{tabular}

For units and abbreviations, see Table 1. For interpretation of the coefficients, see Table 2

${ }^{\text {a }}$ Ethnicity: white British=0, Gambian=1

${ }^{\mathrm{b}}$ Data for CTX and iCa are presented. BTMs showed collinearity, and therefore, models could only include one BTM. For OC and BAP, there was also collinearity with iCa. Separate analyses with individual BTMs or iCa yielded similar results

Table 5 Simple regression analysis: predictors of $\mathrm{uP} / \mathrm{uCr}(\mathrm{ln}$, $\mathrm{mmol} / \mathrm{mmol}$ ) in British and Gambian participants

\begin{tabular}{|c|c|c|}
\hline Independent variable & $\begin{array}{l}\text { British }(n=60) \\
\text { Coeff. }(95 \% \text { CI) }\end{array}$ & $\begin{array}{l}\text { Gambian }(n=61) \\
\text { Coeff. }(95 \% \text { CI })\end{array}$ \\
\hline Age & $-0.03(-0.05,-0.005)^{*}$ & $0.01(-0.02,0.04)$ \\
\hline $\operatorname{Sex}^{\mathrm{a}}$ & $-0.30(-0.48,-0.03)^{*}$ & $-0.15(-0.42,0.10)$ \\
\hline (ln)Weight & $-0.21(-0.72,0.29)$ & $-0.43(-1.31,0.43)$ \\
\hline$(\ln ) \mathrm{Ht}$ & $-1.44(-3.06,0.17)$ & $-1.59(-3.96,0.78)$ \\
\hline$(\ln ) \mathrm{BMI}$ & $0.07(-0.49,0.65)$ & $-0.02(-1.18,1.15)$ \\
\hline$(\ln ) \mathrm{iCa}$ & $1.47(-0.48,3.42)$ & $3.31(1.50,5.13)^{* *}$ \\
\hline (ln)pCaAlb & $1.15(-0.60,2.91)$ & $0.68(-2.00,3.36)$ \\
\hline$(\ln ) \mathrm{pP}$ & $0.93(0.21,1.65)^{*}$ & $0.78(0.05,1.52)^{*}$ \\
\hline$(\ln ) 25(\mathrm{OH}) \mathrm{D}$ & $0.03(-0.18,0.25)$ & $0.45(-0.02,0.92)$ \\
\hline$(\ln ) 1,25(\mathrm{OH})_{2} \mathrm{D}$ & $-0.05(-0.37,0.28)$ & $0.31(-0.18,0.80)$ \\
\hline$(\ln ) \mathrm{PTH}$ & $0.17(0.03,0.31)^{*}$ & $0.23(-0.01,0.47)$ \\
\hline$(\ln ) \mathrm{FGF}$ & $0.03(-0.12,0.18)$ & $-0.01(-0.14,0.14)$ \\
\hline$(\ln ) K_{1 o t h o}{ }^{c}$ & $0.39(-0.02,0.81)^{*}$ & $0.15(-0.15,0.45)$ \\
\hline (ln)P1NP & $0.19(-0.05,0.43)$ & $0.39(0.10,0.68)^{* *}$ \\
\hline$(\ln ) \mathrm{OC}^{\mathrm{b}}$ & $0.05(-0.11,0.21)$ & $0.50(0.29,0.70)^{* *}$ \\
\hline$(\ln ) \mathrm{BAP}^{\mathrm{b}}$ & $0.07(-0.07,0.21)$ & $0.39(0.18,0.59)^{* *}$ \\
\hline$(\ln ) \mathrm{CTX}^{\mathrm{b}}$ & $0.21(0.01,0.41)^{*}$ & $0.10(-0.19,0.40)$ \\
\hline (ln)Diet energy & $-0.32(-0.68,0.05)^{*}$ & $-0.48(-0.85,-0.11)^{*}$ \\
\hline (ln)Diet $\mathrm{Ca}$ & $-0.24(-0.63,0.14)$ & $-0.25(-0.54,0.03)^{*}$ \\
\hline (ln)Diet P & $-0.19(-0.68,0.29)$ & $-0.45(-0.80,-0.10)^{*}$ \\
\hline (ln)Diet $\mathrm{Ca} / \mathrm{P}$ & $-0.36(-1.05,0.31)$ & $0.09(-0.44,0.63)$ \\
\hline
\end{tabular}

For units and abbreviations, see Table 1. For interpretation of the coefficients, see Table 2

${ }^{\text {a }}$ Sex: female $=0$, male $=1$

${ }^{\mathrm{b}}$ Dummy variable for study was included

${ }^{\mathrm{c}}$ Regression analysis with $n=30$ in the UK and $n=31$ in The Gambia $* P<0.05 ; * * P<0.01$
Predictors of $\mathrm{uCa} / \mathrm{uCr}$ in simple regression

Table 2 shows the results of simple regression analysis in data for the two ethnic groups separately. Predictors of $\mathrm{uCa} / \mathrm{uCr}$ were sex, iCa, P1NP, OC, BAP and CTX in white British participants and height, $p \mathrm{P}, \mathrm{P} 1 \mathrm{NP}$, dietary $\mathrm{P}$ and dietary $\mathrm{Ca} / \mathrm{P}$ in Gambian participants.

Table 3 shows the results of the simple regression analysis of the predictors of $\mathrm{uCa} / \mathrm{uCr}$ for the two groups combined. The interaction term of ethnicity $\times$ height and ethnicity $\times \mathrm{pP}$ was significant in the regression model of height and $\mathrm{pP}$ on $\mathrm{uCa} /$ $\mathrm{uCr}$, indicating a difference in the relationship of these variables and $\mathrm{uCa} / \mathrm{uCr}$ between groups. When adjusted for ethnicity, only $\mathrm{iCa}, \mathrm{P} 1 \mathrm{NP}, \mathrm{OC}$, BAP and CTX were significant predictors of $\mathrm{uCa} / \mathrm{uCr}$. Ethnicity was a significant predictor of $\mathrm{uCa} / \mathrm{uCr}$ in all models $(P<0.001)$.

\section{Predictors of $\mathrm{uCa} / \mathrm{uCr}$ in multiple regression}

Table 4 shows the results of multiple regression analysis. In the multiple regression model without ethnicity, the predictors of $\mathrm{uCa} / \mathrm{uCr}$ were dietary $\mathrm{Ca}, \mathrm{iCa}, \mathrm{pP}$ and $\mathrm{CTX}$. When ethnicity was included, $\mathrm{uCa} / \mathrm{uCr}$ was significantly predicted by ethnicity and the same variables as the previous model, except dietary $\mathrm{Ca}$. A final model was constructed to examine the independent effects of dietary $\mathrm{Ca}$ and ethnicity by forcing dietary $\mathrm{Ca}$ into the end model. In this multiple regression model, ethnicity remained a significant predictor of $\mathrm{uCa} / \mathrm{uCr}$, and dietary $\mathrm{Ca}$ was no longer significant.

Due to collinearity, the bone turnover markers (BTMs) (P1NP, CTX, OC and BAP) could not be included in the same models. In addition, iCa showed collinearity with $\mathrm{OC}$ and BAP. All models with a single BTM or iCa had similar results; therefore, the results for CTX and iCa are shown. 
Table 6 Simple regression analysis: predictors of $\mathrm{uP} / \mathrm{uCr}(\ln$, $\mathrm{mmol} / \mathrm{mmol}$ ) in combined data from British and Gambian participants $(n=121)$

\begin{tabular}{lll}
\hline Independent variable & $\begin{array}{l}\text { Independent variable } \\
\text { Coeff. }(95 \% \mathrm{CI})\end{array}$ & $\begin{array}{l}\text { Ethnicity } \mathrm{b}, \mathrm{c} \\
\text { Coeff. }(95 \% \mathrm{CI})\end{array}$ \\
\hline Age & $-0.01(-0.02,0.01)$ & $-0.28(-0.45,-0.12)^{* *}$ \\
Sex $^{\mathrm{a}}$ & $-0.23(-0.39,0.07)^{*}$ & $-0.31(-0.46,-0.15)^{* *}$ \\
$(\ln )$ Weight & $-0.30(-0.78,0.17)$ & $-0.38(-0.61,-0.16)^{* *}$ \\
$(\ln ) \mathrm{Ht}$ & $-1.51(-2.94,-0.09)^{*}$ & $-0.36(-0.53,-0.18)^{* *}$ \\
$(\ln ) \mathrm{BMI}$ & $0.05(-0.52,0.62)$ & $-0.28(-0.48,-0.07)^{* *}$ \\
$(\ln ) \mathrm{iCa}$ & $2.66(1.32,3.99)^{* *}$ & $-0.29(-0.45,-0.13)^{* *}$ \\
$(\ln ) \mathrm{pCaAlb}$ & $0.93(-0.63,2.51)$ & $-0.26(-0.43,-0.09)^{* *}$ \\
$(\ln ) \mathrm{pP}$ & $0.83(0.31,1.35)^{* *}$ & $-0.32(-0.48,-0.16)^{* *}$ \\
$(\ln ) 25(\mathrm{OH}) \mathrm{D}$ & $0.14(-0.07,0.36)$ & $-0.35(-0.53,-0.18)^{* *}$ \\
$(\ln ) 1,25(\mathrm{OH})_{2} \mathrm{D}$ & $0.11(-0.18,0.41)$ & $-0.34(-0.56,-0.12)^{* *}$ \\
$(\ln ) \mathrm{PTH}$ & $0.19(0.06,0.33)^{*}$ & $-0.39(-0.58,-0.21)^{* *}$ \\
$(\ln ) \mathrm{FGF}$ & $0.01(-0.09,0.11)$ & $-0.29(-0.46,-0.12)^{* *}$ \\
$(\ln ) \mathrm{Klotho}$ & $0.20(-0.03,0.44)$ & $-0.57(-0.76,-0.38)^{* *}$ \\
$(\ln ) \mathrm{P} 1 \mathrm{NP}$ & $0.30(0.11,0.49)^{* *}$ & $-0.47(-0.66,-0.27)^{* *}$ \\
$(\ln ) \mathrm{OC}{ }^{\mathrm{d}}$ & $0.05(-0.12,0.23)$ & $-1.79(-2.59,-0.99)$ \\
$(\ln ) \mathrm{BAP}{ }^{\mathrm{d}}$ & $0.07(-0.09,0.23)$ & $-1.29(-2.04,-0.54)$ \\
$(\ln ) \mathrm{CTX}{ }^{\mathrm{d}}$ & $0.16(-0.01,0.33)$ & $-0.41(-0.62,-0.19)^{* *}$ \\
$(\ln ) \mathrm{Diet}$ energy & $-0.42(-0.68,-0.16)$ & $-0.41(-0.59,-0.24)^{* *}$ \\
$(\ln ) \mathrm{Diet} \mathrm{Ca}$ & $-0.25(-0.47,-0.03)$ & $-0.64(-0.99,-0.29)^{* *}$ \\
$(\ln ) \mathrm{Diet} \mathrm{P}$ & $-0.39(-0.66,-0.12)$ & $-0.59(-0.86,-0.32)^{* *}$ \\
$(\ln )$ Diet Ca/P & $-0.01(-0.42,0.39)$ & $-0.29(-0.59,0.01)^{* *}$ \\
\hline & & \\
\hline
\end{tabular}

${ }^{\mathrm{a}}$ Sex: female $=0$, male $=1$

${ }^{\mathrm{b}}$ The coefficient of the $\mathrm{OC} \times$ ethnicity interaction was $\beta=0.44(0.18$, $0.70), P=0.001$; the coefficient of the BAP $\times$ ethnicity interaction was $\beta=0.32(0.07,0.57)$. For units and abbreviations, see Table 1 . For interpretation of the coefficients, see Table 2. For ethnicity, see Table 3

${ }^{\mathrm{c}}$ See Table 3

${ }^{\mathrm{d}}$ Dummy variable for study was included

${ }^{\mathrm{e}}$ Regression analysis with $n=30$ in the UK and $n=31$ in The Gambia

$* P<0.05 ; * * P<0.01$

Predictors of $\mathrm{uP} / \mathrm{uCr}$ in simple regression

Table 5 shows the simple regression analysis in data from each ethnic group separately. Predictors of $\mathrm{uP} / \mathrm{uCr}$ were age, sex, pP, PTH, Klotho, CTX and dietary energy intake in white British participants and $\mathrm{iCa}, \mathrm{pP}, \mathrm{P} 1 \mathrm{NP}, \mathrm{OC}, \mathrm{BAP}$, dietary energy, dietary $\mathrm{Ca}$ and dietary $\mathrm{P}$ in Gambian participants.

Table 6 shows the results of the simple regression analysis of the predictors of $\mathrm{uP} / \mathrm{uCr}$ in data from the groups combined. There was a significant interaction of ethnicity $\times \mathrm{OC}$ and ethnicity $\times$ BAP, indicating a difference in the relationship of these variables and $\mathrm{uP} / \mathrm{uCr}$ between groups. When adjusted for ethnicity, sex, height, iCa, pP, PTH and P1NP were significant predictors of $\mathrm{uP} / \mathrm{uCr}$. Ethnicity was a significant predictor of $\mathrm{uP} / \mathrm{uCr}$ in all models $(P<0.001)$.
Predictors of $\mathrm{uP} / \mathrm{uCr}$ in multiple regression

Table 7 shows the results of the multiple regression analysis. In the multiple regression model without ethnicity, the predictors of $\mathrm{uP} / \mathrm{uCr}$ were dietary $\mathrm{Ca} / \mathrm{P}, \mathrm{iCa}, \mathrm{pP}$ and $\mathrm{PTH}$. When ethnicity was included, $\mathrm{uP} / \mathrm{uCr}$ was predicted by ethnicity and the same variables as the previous model, except dietary $\mathrm{Ca} / \mathrm{P}$. A final model was constructed to examine the independent effects of dietary $\mathrm{Ca} / \mathrm{P}$ and ethnicity by forcing dietary $\mathrm{Ca} / \mathrm{P}$ into the end model with ethnicity. In this multiple regression model, ethnicity remained a significant predictor of $\mathrm{uP} / \mathrm{uCr}$, and dietary $\mathrm{Ca} / \mathrm{P}$ was no longer a significant predictor.

Due to collinearity, iCa, OC and BAP were not included in the same model. They all exhibited a significant positive association with $\mathrm{uP} / \mathrm{uCr}$ in separate multiple regression models (data not shown).

\section{Discussion}

This cross-sectional study has shown that white British older adults have a significantly higher urinary $\mathrm{Ca}(+121 \%)$ and $\mathrm{P}$ $(+29 \%)$ excretion, higher fractional $\mathrm{Ca}$ and $\mathrm{P}$ excretion and $\mathrm{a}$ lower tubular maximum for $\mathrm{Ca}$ and $\mathrm{P}$ than Gambian counterparts under fasting conditions. This is in agreement with the high degree of $\mathrm{Ca}$ conservation observed in this Gambian population [31] and in agreement known adaptive mechanisms to a low $\mathrm{Ca}$ intake and a concomitant elevated PTH as described in predominantly white populations [37] [38]. Although white British participants had a higher dietary $\mathrm{Ca}$ and $\mathrm{P}$ intake and lower PTH, 1,25(OH $)_{2} \mathrm{D}$ and BTMs compared to the Gambians, multiple regression models showed that significant ethnic differences remained after consideration of differences in these dietary and regulatory factors. This suggests that ethnicity has an independent effect on renal $\mathrm{Ca}$ and $\mathrm{P}$ handling. This may contribute to the observed differences in $\mathrm{Ca}$ and $\mathrm{P}$ balance and bone metabolism between these two groups.

Differences in renal mineral handling have also been previously reported between other racial or ethnic groups. They are thought to be partly related to differences in the sensitivity of the renal-bone axis to the actions of PTH; where a chronic elevation of plasma PTH and a high rate of bone turnover are considered risk factors for bone loss and fragility fractures in white populations, these relationships are less clear in other population groups $[5,23,39]$. The mechanistic basis of these differences is unclear, but may relate to epigenetic changes or variations in genes related to $\mathrm{Ca}$ and $\mathrm{P}$ metabolism, such as those involved in renal and intestinal handling of $\mathrm{Ca}$ and $\mathrm{P}$ $[21,40]$, their dietary sources, such as dairy products [41], or in vitamin D metabolism [42, 43], or relate to further 
Table 7 Multiple regression analysis: predictors of $\mathrm{uP} / \mathrm{uCr}(\mathrm{ln}, \mathrm{mmol} / \mathrm{mmol})$ in combined data from British and Gambian participants $(n=121)$

\begin{tabular}{|c|c|c|c|c|c|c|c|c|}
\hline \multicolumn{3}{|c|}{ Without ethnicity included } & \multicolumn{3}{|c|}{ With ethnicity included } & \multicolumn{3}{|c|}{ With dietary $\mathrm{Ca} / \mathrm{P}$ forced in } \\
\hline & Coeff. & $P$ & & Coeff. & $P$ & & Coeff. & $P$ \\
\hline $\begin{array}{l}\text { (ln)Dietary } \\
\mathrm{Ca} / \mathrm{P}\end{array}$ & $\begin{array}{l}0.43 \\
(0.21,0.66)\end{array}$ & $<0.001$ & Ethnicity & $\begin{array}{l}-0.45 \\
(-0.62,-0.28)\end{array}$ & $<0.001$ & Ethnicity $^{\mathrm{a}}$ & $\begin{array}{l}-0.46 \\
(-0.74,-0.19)\end{array}$ & 0.001 \\
\hline$(\ln ) \mathrm{iCa}^{\mathrm{b}}$ & $\begin{array}{l}2.77 \\
(1.47,4.06)\end{array}$ & $<0.0001$ & $(\ln ) \mathrm{iCa}^{\dagger}$ & $\begin{array}{l}2.96 \\
(1.72,4.20)\end{array}$ & $<0.001$ & $(\ln ) \mathrm{iCa}^{\mathrm{a}}$ & $\begin{array}{l}3.06 \\
(1.81,4.31)\end{array}$ & $<0.001$ \\
\hline$(\ln ) \mathrm{pP}$ & $\begin{array}{l}0.86 \\
(0.36,1.35)\end{array}$ & 0.001 & $(\ln ) \mathrm{pP}$ & $\begin{array}{l}0.86 \\
(0.38,1.33)\end{array}$ & $<0.001$ & $(\ln ) \mathrm{pP}$ & $\begin{array}{l}0.88 \\
(0.41,1.35)\end{array}$ & $<0.001$ \\
\hline \multirow[t]{2}{*}{$(\ln ) \mathrm{PTH}$} & $\begin{array}{l}0.15 \\
(-1.00,0.15)\end{array}$ & 0.015 & $(\ln ) \mathrm{PTH}$ & $\begin{array}{l}0.22 \\
(0.09,0.34)\end{array}$ & $<0.001$ & (ln)PTH & $\begin{array}{l}0.21 \\
(0.08,0.32)\end{array}$ & 0.001 \\
\hline & & & & & & $(\ln )$ Dietary $\mathrm{Ca} / \mathrm{P}$ & $\begin{array}{l}-0.04 \\
(-0.39,0.31)\end{array}$ & 0.8 \\
\hline
\end{tabular}

For units and abbreviations, see Table 1. For interpretation of the coefficients, see Table 2

${ }^{\text {a }}$ Ethnicity: white British=0, Gambian 1

${ }^{\mathrm{b}}$ Data for $\mathrm{iCa}$ are presented. iCa showed collinearity with OC and BAP. Separate analyses for iCa or OC or BAP yielded similar results

environmental and lifestyle differences that exist between different ethnic groups. These differences in mineral metabolism may influence the rate of bone turnover and age-related deterioration of bone micro-architecture, integrity and bone fragility [44].

The finding that dietary $\mathrm{Ca}$ was a significant predictor of $\mathrm{uCa} / \mathrm{uCr}$ and that dietary $\mathrm{Ca} / \mathrm{P}$ ratio was a significant predictor of $\mathrm{uP} / \mathrm{uCr}$ in multiple regression models confirms that their dietary intakes are an important driver of the differences in urinary mineral excretion between groups. However, when the regression models were adjusted for ethnicity, dietary intake was no longer a predictor of urinary $\mathrm{Ca}$ or $\mathrm{P}$ excretion, suggesting that in this study, ethnicity was closely related to dietary mineral intake and that within an ethnic group, dietary intake of $\mathrm{Ca}$ and $\mathrm{P}$ was not a significant factor.

Our findings support previous studies in the USA that have shown that racial or ethnic differences in renal mineral handling cannot be fully explained by differences in dietary mineral intake $[15,16,18,20,45]$. In our study, we did not standardise dietary intakes, as we wished to investigate mineral handling under habitual circumstances. Any change in dietary mineral intake will lead to changes in the $\mathrm{Ca}$ and $\mathrm{P}$ balance, their regulators and the bone mineral remodelling cycle, known as the bone remodelling transient [46]. A new steady state of mineral balance is first reached after several weeks or even months. Therefore, studies under non-habitual standardised conditions may not reflect the ethnic differences in steady state [38].

The predictors of $\mathrm{uCa} / \mathrm{uCr}$ differed between Gambian and white British participants, as evidenced by differences in predictors when groups were analysed separately and the significant ethnicity $\times$ plasma $\mathrm{P}$ interaction term (Tables 2 and 3). In The Gambia, there was a significant negative relationship with plasma $\mathrm{P}$ or dietary $\mathrm{P}$ and $\mathrm{uCa} / \mathrm{uCr}$, but these relationships were not observed in the UK. This suggests that
P metabolism may be an important factor to consider when investigating ethnic differences in urinary $\mathrm{Ca}$ excretion under fasting conditions. Under conditions of a low dietary $\mathrm{Ca} / \mathrm{P}$ intake, such as in The Gambia, a relatively high fractional intestinal absorption of both $\mathrm{Ca}$ and $\mathrm{P}$ occurs [47]. This may result in a lower urinary $\mathrm{Ca}$ excretion per unit of absorbed $\mathrm{P}$ and may explain the negative relationship between plasma $\mathrm{P}$ and $\mathrm{uCa} / \mathrm{uCr}$ that is seen in The Gambia (this study, [31]), but not in the UK.

Although $1,25(\mathrm{OH})_{2} \mathrm{D}$ and FGF-23 are primary regulators of $\mathrm{Ca}$ and $\mathrm{P}$ metabolism, they were not found to be predictors of $\mathrm{uCa} / \mathrm{uCr}$ or $\mathrm{uP} / \mathrm{uCr}$ excretion. PTH was only positively associated with $\mathrm{uP} / \mathrm{uCr}$ excretion. In addition, there was no indication that the relationship between $\mathrm{uCa} / \mathrm{uCr}$ or $\mathrm{uP} / \mathrm{uCr}$ and these calciotropic and phosphaturic hormones differed by ethnicity as the ethnicity interaction terms were nonsignificant for all variables. These factors are interlinked through the intestinal-renal-bone regulatory axis of mineral metabolism. Therefore, the values of measured variables are dependent. This may lead to statistical confounding and minimise their statistical relationship. As a consequence, dietary $\mathrm{Ca}$ may not only act as a predictor of $\mathrm{uCa} / \mathrm{uCr}$ but also for other factors, e.g. ethnicity and the calciotropic hormones.

The BTMs (CTX, P1NP, OC and/or BAP) were predictors of $\mathrm{uCa} / \mathrm{uCr}$ in most models. The ethnicity $\times \mathrm{BTMs}$ interaction terms were not significant for any marker suggesting that the relationships between BTMs and renal Ca handling were not different between groups. The BTMs were also predictors of $\mathrm{uP} / \mathrm{uCr}$, although this did not reach significance for all markers and all models. The interaction term of ethnicity and $\mathrm{OC}$ and BAP was significant; the relationship between $\mathrm{uP} / \mathrm{uCr}$ and $\mathrm{OC}$ or BAP was positive in both ethnic groups, but the coefficient of the relationship was greater in Gambian older adults. This may be due to the higher rate of bone turnover in the Gambian group or may indicate a stronger association between renal $\mathrm{P}$ 
handling and bone remodelling. The positive associations of urinary $\mathrm{Ca}$ and $\mathrm{P}$ excretion with the BTMs may potentially be explained by the expected net loss of mineral from bone in this age group.

This study has several limitations. Although it has been suggested that after an overnight fast, the contribution of intestinal calcium absorption to $\mathrm{uCa}$ is minimised [48], its influence cannot be fully excluded as the transit time of a meal may be longer than the duration of the overnight fast. Therefore, as suggested by our data, even when using fasting $\mathrm{uCa}$ measurements, differences may exist between groups, particularly when they differ substantially in Ca intake and diet composition. $\mathrm{Ca}, \mathrm{P}$ and bone metabolism are known to have a pronounced diurnal rhythm [49] and this rhythm may be expected to differ between groups due to differences in external environmental factors, including patterns of dietary intake. Potential ethnic differences may therefore vary during the 24-h cycle. The participants included in this study represent two groups different in body size and composition, as evidenced by the higher body weight, height, BMI and BSA in British compared to Gambian participants. The amount of mineral and creatinine excreted may be dependent on body mass; to address this, we included weight, height, BMI and body surface area in regression analyses. However, these were not significant predictors of uCa or uP. In addition, when $\mathrm{TmCa}$ and TmP/GFR were corrected for body surface area, this increased, rather than decreased ethnic differences in these variables. This may be further explored by inclusion of lean body mass (unavailable in this study) in these analyses. Renal $\mathrm{Ca}$ reabsorption may be influenced by other factors which may differ by ethnic group, such as sodium intakes [50]; we have performed no measurement of dietary and urinary sodium in this study, but sodium intake in The Gambia is known to be high (personal observation). There may have been other factors associated with ancestry or ethnicity that may have influenced $\mathrm{Ca}$ and $\mathrm{P}$ metabolism that were not accounted for in this study; these may include, e.g. genetic factors, the intake of other nutrients, gastro-intestinal factors and physical activity. There was substantial data clustering in some of the measured variables in this study, in particular for dietary $\mathrm{Ca}$ intake. This was addressed by using an ethnicity interaction term to allow for differences in the intercept and slope of the regression line. This however assumes a linear relationship over the whole range of intakes observed in the study. Since there was very little overlap of the intakes in the UK and The Gambia, it is uncertain that this assumption is correct.

In conclusion, these data demonstrate that there are ethnic differences in renal mineral handling, with a higher urinary $\mathrm{Ca}$ and $\mathrm{P}$ excretion in white British compared to Gambian older adults. Our results show that dietary mineral intake is an important predictor of the ethnic differences in urinary $\mathrm{Ca}$ and $\mathrm{P}$ excretion, but ethnicity remained a strong predictor of urinary $\mathrm{Ca}$ and $\mathrm{P}$ excretion after statistical adjustment for dietary $\mathrm{Ca}$ and $\mathrm{P}$ intake and other variables. This suggests that ethnicity has an independent effect on renal $\mathrm{Ca}$ and $\mathrm{P}$ handling, and these differences may contribute to the observed differences in $\mathrm{Ca}$ and $\mathrm{P}$ balance and bone metabolism. More detailed studies investigating the relationship between mineral homeostasis and bone metabolism, bone mineral density and bone structure in these ethnic groups and at different ages are currently undertaken.

Acknowledgments This research was jointly funded by the Medical Research Council (MRC) and the Department for International Development (DFID) under the MRC/DFID Concordat agreement (MRC Unit Programmes U105960371 and U123261351). JR received a Ph.D. studentship from the MRC. We wish to thank Janet Bennett, Ann Laidlaw and Shailja Nigdikar, MRC Human Nutrition Research, for the laboratory analyses. We wish to also thank the participants of our research studies and the members of staff at MRC Human Nutrition Research and MRC Keneba for their assistance with conducting the studies.

\section{Conflicts of interest None.}

Open Access This article is distributed under the terms of the Creative Commons Attribution Noncommercial License which permits any noncommercial use, distribution, and reproduction in any medium, provided the original author(s) and the source are credited.

\section{References}

1. Kanis J, Oden A, McCloskey EV, Johansson H, Wahl DA, Cooper C (2012) A systematic review of hip fracture incidence and probability of fracture worldwide. Osteoporos Int 23:2239-2256

2. Adebajo AF, Cooper C, Evans JG (1991) Fractures of the hip and distal forearm in West Africa and the United Kingdom. Age Ageing 20:435-438

3. Barrett JA, Baron JA, Karagas MR, Beach ML (1999) Fracture risk in the U.S. Medicare population. J Clin Epidemiol 52:243-249

4. Prentice A, Shaw J, Laskey MA, Cole TJ, Fraser DR (1991) Bone mineral content of British and rural Gambian women aged 18-80+ years. Bone Miner 12:201-214

5. Yan L, Schoenmakers I, Zhou B, Jarjou LM, Smith E, Nigdikar S, Goldberg GR, Prentice A (2009) Ethnic differences in parathyroid hormone secretion and mineral metabolism in response to oral phosphate administration. Bone 45:238-245

6. Aspray TJ, Prentice A, Cole TJ, Sawo Y, Reeve J, Francis RM (1996) Low bone mineral content is common but osteoporotic fractures are rare in elderly rural Gambian women. J Bone Miner Res 11:10191025

7. Megyesi MS, Hunt LM, Brody H (2011) A critical review of racial/ ethnic variables in osteoporosis and bone density research. Osteoporos Int 22:1669-1679

8. Race Ethnicity and Genetics Working Group (2005) The use of racial, ethnic, and ancestral categories in human genetics research. Am J Hum Genet 77:519-532

9. (2002) In Trumble W (ed) Oxford English Dictionary 5th edn. Oxford University Press, New York

10. Cauley J, El-Hajj Fuleihan G, Arabi A et al (2011) Official Positions for FRAX(R) clinical regarding international differences from Joint Official Positions Development Conference of the International Society for Clinical Densitometry and International Osteoporosis Foundation on FRAX(R). J Clin Densitom 14:171-80 
11. Ross PD, Norimatsu H, Davis JW, Yano K, Wasnich RD, Fujiwara S, Hosoda Y, Melton LJ 3rd (1991) A comparison of hip fracture incidence among native Japanese, Japanese Americans, and American Caucasians. Am J Epidemiol 133:801-809

12. Tsang S, Kung AWC, Kanis JA, Johansson H, Oden A (2009) Tenyear fracture probability in Hong Kong Southern Chinese according to age and BMD femoral neck T-scores. Osteoporos Int 20:1939-45

13. Charlton K, Steyn K, Levitt NS, Zulu JV, Jonathan D, Veldman FJ, Nel JH (2005) Ethnic differences in intake and excretion of sodium, potassium, calcium and magnesium in South Africans. Eur J Cardiovasc Prev Rehabil 12:355-362

14. Finkelstein JS, Sowers M, Greendale GA, Lee ML, Neer RM, Cauley JA, Ettinger B (2002) Ethnic variation in bone turnover in pre- and early perimenopausal women: effects of anthropometric and lifestyle factors. J Clin Endocrinol Metab 87:3051-3056

15. Taylor EF, Curhan GC (2007) Differences in 24-hour urine composition between black and white women. J Am Soc Nephrol 18:654659

16. Dawson-Hughes B, Harris SS, Finneran S, Rasmussen HM (1995) Calcium absorption responses to calcitriol in black and white premenopausal women. J Clin Endocrinol Metab 80:3068-3072

17. Bell NH, Yergey AL, Vieira NE, Oexmann MJ, Shary JR (1993) Demonstration of a difference in urinary calcium, not calcium absorption, in black and white adolescents. J Bone Miner Res 8:1111-1115

18. Dawson-Hughes B, Harris S, Kramich C, Dallal G, Rasmussen HM (1993) Calcium retention and hormone levels in black and white women on high- and low-calcium diets. J Bone Miner Res 8:779-787

19. Braun M, Palacios C, Wigertz K, Jackman LA, Bryant RJ, McCabe LD, Martin BR, Peacock M, Weaver CM (2007) Racial differences in skeletal calcium retention in adolescent girls with varied controlled calcium intakes. Am J Clin Nutr 85:1657-1663

20. Gutierrez O, Isakova T, Smith K, Epstein M, Patel N, Wolf M (2010) Racial differences in postprandial mineral ion handling in health and in chronic kidney disease. Nephrol Dial Transplant 25:3970-3977

21. Walker MD, Novotny R, Bilezikian JP, Weaver CM (2008) Race and diet interactions in the acquisition, maintenance, and loss of bone. $\mathrm{J}$ Nutr 138:1256S-1260S

22. Aspray TJ, Yan L, Prentice A (2005) Parathyroid hormone and rates of bone formation are raised in perimenopausal rural Gambian women. Bone 36:710-720

23. Prentice A, Laskey MA, Shaw J, Hudson GJ, Day KC, Jarjou LM, Dibba B, Paul AA (1993) The calcium and phosphorus intakes of rural Gambian women during pregnancy and lactation. Br J Nutr 69: 885-896

24. Prentice A (2008) Vitamin D deficiency: a global perspective. Nutr Rev 66:S153-164

25. Mosteller RD (1987) Simplified calculation of body-surface area. N Engl J Med 317:1098

26. Agency FS (2002) McCance and Widdowson's the composition of foods. Royal Society of Chemistry, Cambridge

27. Masson LF, McNeill G, Tomany JO, Simpson JA, Peace HS, Wei L, Grubb DA, Bolton-Smith C (2003) Statistical approaches for assessing the relative validity of a food-frequency questionnaire: use of correlation coefficients and the kappa statistic. Public Health Nutr 6:313-321

28. Jarjou L, Prentice A, Sawo Y, Laskey MA, Bennett J, Goldberg GR, Cole TJ (2006) Randomized, placebo-controlled, calcium supplementation study in pregnant Gambian women: effects on breast-milk calcium concentrations and infant birth weight, growth, and bone mineral accretion in the first year of life. Am J Clin Nutr 83:657-666

29. Prynne C, Paul AA (2007) Food composition table for use in The Gambia. MRC Human Nutrition Research, Cambridge

30. Payne R, Carver ME, Morgan DB (1979) Interpretation of serum total calcium: effects of adjustment for albumin concentration on frequency of abnormal values and on detection of change in the individual. J Clin Pathol 32:56-60

31. Schoenmakers I, Jarjou LMA, Goldberg GR, Tsoi K, Harnpanich D, Prentice A (2013) Acute response to oral calcium loading in pregnant and lactating women with a low calcium intake: a pilot study. Osteoporos Int 24:2301-2308

32. Kent GN, Bhagat CI, Garcia-Webb P, Gutteridge DH (1987) Tubular maximum for calcium reabsorption: lack of diagnostic usefulness in primary hyperparathyroidism and familial hypocalciuric hypercalcaemia. Clin Chim Acta 166:155-161

33. Burnett S, Gunawardene SC, Bringhurst FR, Juppner H, Lee H, Finkelstein JS (2006) Regulation of C-terminal and intact FGF-23 by dietary phosphate in men and women. J Bone Miner Res 21:11871196

34. Barth J, Jones RG, Payne RB (2000) Calculation of renal tubular reabsorption of phosphate: the algorithm performs better than the nomogram. Ann Clin Biochem 37:79-81

35. Eastwood JB, Kerry SM, Plange-Rhule J, Micah FB, Antwi S, Boa FG, Banerjee D, Cappuccio FP (2010) Assessment of GFR by four methods in adults in Ashanti, Ghana: the need for an eGFR equation for lean African populations. Nephrol Dial Transplant 25:2178-2187

36. Cole TJ (2000) Sympercents: symmetric percentage differences on the $100 \log (\mathrm{e})$ scale simplify the presentation of $\log$ transformed data. Stat Med 19:3109-3125

37. Heaney R (2006) The calcium economy. In: Weaver C, Heaney R (eds) Calcium in Human Health, 1st edn. Humana, Totowa, pp 145162

38. Malm OJ (1958) Calcium requirement and adaptation in adult men. Scand J Clin Lab Invest 10(Supp 36):1-290

39. Delmas PD, Eastell R, Garnero P, Seibel MJ, Stepan J (2000) The use of biochemical markers of bone turnover in osteoporosis Committee of Scientific Advisors of the International Osteoporosis Foundation. Osteoporos Int 11(Suppl 6):S2-17

40. Thorleifsson G, Holm H, Edvardsson V et al (2009) Sequence variants in the CLDN14 gene associate with kidney stones and bone mineral density. Nat Genet 41:926-930

41. Olds LC, Ahn JK, Sibley E (2011) $13915^{*} \mathrm{G}$ DNA polymorphism associated with lactase persistence in Africa interacts with Oct-1. Hum Genet 129:111-113

42. Signorello LB, Shi J, Cai Q et al (2011) Common variation in vitamin D pathway genes predicts circulating 25-hydroxyvitamin D Levels among African Americans. PLoS One 6:e28623

43. Kamboh MI, Ferrell RE (1986) Ethnic variation in vitamin D-binding protein $(\mathrm{GC})$ : a review of isoelectric focusing studies in human populations. Hum Genet 72:281-293

44. Schnitzler CM (1993) Bone quality: a determinant for certain risk factors for bone fragility. Calc Tiss Int 53:S27-31

45. Bell NH, Greene A, Epstein S, Oexmann MJ, Shaw S, Shary J (1985) Evidence for alteration of the vitamin D-endocrine system in blacks. J Clin Invest 76:470-473

46. Prentice A (2004) Diet, nutrition and the prevention of osteoporosis. Public Health Nutr 7:227-243

47. Christakos S, Lieben L, Masuyama R, Carmeliet G (2014) Vitamin D endocrine system and the intestine. Bonekey Rep 3:496

48. Peacock M, Knowles F, Nordin BE (1968) Effect of calcium administration and deprivation on serum and urine calcium in stoneforming and control subjects. Br Med J 2:729-731

49. Greenspan SL, Dresner-Pollak R, Parker RA, London D, Ferguson L (1997) Diurnal variation of bone mineral turnover in elderly men and women. Calcif Tissue Int 60:419-423

50. Blackwood A, Sagnella GA, Cook DG, Cappuccio FP (2001) Urinary calcium excretion, sodium intake and blood pressure in a multi-ethnic population: results of the Wandsworth Heart and Stroke Study. J Hum Hypertens 15:229-237 